\title{
The Ethyl Acetate Subfraction of Polygonum Cuspidatum Root Containing Emodin Induce EBV- Positive Cells Apoptosis
}

\author{
Ching-Yi Yiu ${ }^{1,2}$, Yu-Jhe Chiu ${ }^{1}$ and Tsuey-Pin Lin ${ }^{1 *}$ \\ ${ }^{1}$ Department of Health and Nutrition, Chia-Nan University of Pharmacy and Science, Tainan, Taiwan
}

${ }^{2}$ Department of Otolaryngology, Chi Mei Medical Center, Liouying, Tainan, Taiwan

*Corresponding author: Tsuey-Pin Lin, Department of Health and Nutrition, Chia-Nan University of Pharmacy and Science, Tainan, Taiwan

\begin{abstract}
ARTICLE INFO
Received: May 06, 2021

Published: 蔧 May 18, 2021

Citation: Ching-Yi Yiu, Yu-Jhe Chiu, TsueyPin Lin. The Ethyl Acetate Subfraction of Polygonum Cuspidatum Root Containing Emodin Induce EBV-Positive Cells Apoptosis. Biomed J Sci \& Tech Res 35(5)-2021. BJSTR. MS.ID.005767.

Keywords: Epstein-Barr virus; Latent

ABSTRACT

Epstein-Barr Virus (EBV), a human herpesvirus, is several human lymphoid malignancies-associated. Our earlier study found the effect of Polygonum cuspidatum root on promoting EBV-positive apoptosis. Therefore, this study investigated the effects of the Polygonum cuspidatum ethyl acetate subfraction containing emodin on EBV gene expression and anti-EBV tumor cells. Resultantly, the Polygonum cuspidatum ethyl acetate subfraction containing emodin (F3a) promoted Raji cell death $\left(\mathrm{CC}_{50}: 12.08 \mu \mathrm{g} /\right.$ $\mathrm{mL}$ ); the $12.5 \mu \mathrm{g} / \mathrm{mL} \mathrm{F3a}$ effect transcribed BRLF1 and BNLF1 and increased LMP1, which reduced the intracellular phospho-ERK and phospho- IкB $\alpha$. Meanwhile, the Raji cells increased the intracellular Reactive-Oxygen Species (ROS), activated the apoptosisrelated proteins, cleaved caspase 3 and PARP, and increased the apoptosis percentage. Therefore, the Polygonum cuspidatum ethyl acetate subfraction containing emodin could be a therapeutic drug for EBV-related tumors.
\end{abstract} Membrane Protein 1; Polygonum Cuspidatum; ROS; Emodin
Abbreviations: EBV: Epstein-Barr Virus; ROS: Reactive-Oxygen Species; TPA: Tetradecanoylphorbol-13-Acetate; LMP: Latent Membrane Protein; qPCR: quantitative PCR

\section{Introduction}

EBV infects lymphocytes and epithelial cells [1] and leads to infectious mononucleosis [2] and various malignant diseases including: Burkitt's lymphoma [3]; T-cell lymphoma [4]; Hodgkin's disease [5]; gastric cancer [6]; nasopharyngeal carcinoma [7]. The virus enters the latent period [8] after infection with B lymphocytes, but when exposed to external factors including ultraviolet [9], 12-0-Tetradecanoylphorbol-13-Acetate (TPA) [10], or sodium butyrate (SB) [11], it will enter the lytic cycle to proliferate and then infect other cells. It importantly correlates the EBV-related malignant diseases. During the lytic cycle, the virus will express two earlier-early genes, BRLF1 and BZLF1, which can express the transcription factors, Rta and Zta [12], respectively. These two transcription factors can interact with each other or alone to activate others lytic genes, including BMRF1 and BALF5, encoded diffused Early Antigen (EA-D) and DNA polymerase [13], respectively. The EBV-BNLF1 encoded LMP (Latent Membrane Protein) 1 , is an oncogene that directly induce NF- $\mathrm{BB}$ activation or by stimulating phosphorylation of ERK to activate NF- $\mathrm{B}$, it has the functions of anti-apoptosis, promoting cell proliferation and immortality [14].

The BNLF1 gene expression, are positive-regulated by EBNA1 [15], EBNA2 [16] and lytic protein, Rta [17]. The EBV infecting B lymphocytes induce Reactive Oxygen Species (ROS) via the LMP1. However, when LMP 1 was overexpressed, it induced ROS and regulated the related signal transduction mechanism, including down-regulating NF- $\mathrm{KB}$ and inducing cell necrosis or apoptosis 
[18]. Valko et al. pointed that ROS with the race concentration in the cells could be the cell free radical scavenging system-eliminated. With the excessive concentration, gene mutation and apoptosis probably came directly [19]. Polygonum cuspidatum, herbal, is common for treating atherosclerosis, as well as others including cancers; asthma; hypertension; cough [20]. The root ethanol extract contains anthraglycoside $\mathrm{B}$, physcion, piceid, emodin and resveratrol [21]. The previous studies found the extract effect on EBV tumor cell death [22], inhibiting EBV lytic cycle induced by sodium butyrate [23-25] and hepatitis B virus replication [26]. Therefore, this study was to explore the F3a effects on EBV gene expression and apoptosis of EBV-positive tumor cell.

\section{Materials and Methods}

\section{Plant Material}

Taiwan Pingtung County San-Dei-Men P. cuspidatum in the Taiwan Tainan National Cheng Kung University herbarium was Prof. C. S. Kuoh-verified.

\section{Sample Preparation}

The 10-g dried P. cuspidatum root powder was extracted 3 times in $100 \mathrm{~mL}$ ethanol by refluxing at $85^{\circ} \mathrm{C}$ for $2 \mathrm{~h}$. After each extraction, the ethanol fractions were filtration-collected and hexane and water (10:10:1)-partitioned twice. The aqueous fractions were collected and concentrated under reduced pressure: $\mathrm{PcE}(\mathrm{H})$. The $1 \mathrm{~g}$ dried $\mathrm{PcE}(\mathrm{H})$ was $100 \mathrm{~mL}$ distilled water-dissolved and equal volume ethyl acetate (EtOAc)-partitioned. The EtOAc fractions were collected and concentrated under reduced pressure: PcE(H)E. The PcE(H)E soluble fraction was subjected to semi-preparative HPLC using HYPERPREP C18 (150 x $10 \mathrm{~mm}$ i.d., $8 \mathrm{~mm}$ ) column (Thermo Fisher, MA, USA), and the peak eluted at 30.48 min using the mobile phase by:

\section{a) Water \\ b) Methanol}

Gradient eluting was: $30-50 \%$ B in 0-15 min; $50-90 \%$ B in 15 $35 \mathrm{~min} ; 95 \%$ B in 35-45 min. An ethylacetate subfraction F3a and the $0.044 \%$ were collected. The resulting residues were finally dimethyl sulfoxide (DMSO)-dissolved.

\section{HPLC Analysis}

The F3a components were HPLC-analyzed using a LiChrospher 100 RP-18e ( 250 x 4.6 mm i.d., 5 mm) column (Merck, Darmstadt, Germany). The mobile phase consisted of:
a) Water
b) Methanol

Gradient eluting was: $30-50 \%$ B in $0-15 \mathrm{~min}$; $50-90 \%$ B in $15-$ $35 \mathrm{~min} ; 95 \% \mathrm{~B}$ in $35-45 \mathrm{~min}$. The flow rate was at $1 \mathrm{~mL} / \mathrm{min}$. The effluent from 210 to $500 \mathrm{~nm}$ was a diode array detector-monitored.

\section{F3a Identification}

${ }^{1} \mathrm{H}$ NMR $(200 \mathrm{MHz})$ and ${ }^{13} \mathrm{C}$ NMR (50 MHz) were the Bruker Advance 200 spectrometer-recorded. The F3a was identified as emodin by comparing the emodin NMR spectral data with those in the literatures [21].

F3a was,

${ }^{1} \mathrm{H}$ NMR (200 MHz, DMSO) $\delta: 12.17$ (1H, each, s, OH); $7.45(1 \mathrm{H}$, s, H-4); 7.13 (1H, s, H-5); 7.03 (1H, s, H-2); 6.459 (1H, s, H-7); 2.39 $\left(3 \mathrm{H}, \mathrm{s}, \mathrm{CH}_{3}\right)$.

${ }^{13} \mathrm{C}$ NMR (50 MHz, DMSO) $\delta: 147.91(\mathrm{C}-3) ; 124.45$ (C-4); 182.31 (C-10); 133.28 (C-4a); 114.06 (C-9a); 135.29 (C-10a); $21.91\left(-\mathrm{CH}_{3}\right.$ ).

\section{Cell Culture and F3a Treatment}

The Burkitt's lymphoma-derived Raji cells, EBV-positive cells, were maintained in the RPMI 1640 medium contained-10\% fetal calf serum (Biological Industries, Israel). The Chang-Gung University Prof. S.T. Liu-obtained Raji cells ( $\left.6 \times 10^{5} / \mathrm{mL}\right)$, were the $24 \mathrm{~h}$ F3a different concentrations-treated. The viable cell number was trypan blue dye exclusion-counted by a hemocytometer. The result was as a percentage, relative to vehicle-treated control incubations, and the $\mathrm{CC}_{50}$ values were the non-linear regression analysis (percent survival versus concentration)-calculated.

\section{RNA Extraction}

Conventional Trizol-chloroform (Invitrogen, Carlsbad, CA)extracted RNA was from the $3 \times 10^{6}$ cells. DNA removing was by RNase-Free DNase (Promega, Madison, WI)). Total RNA was added to high capacity cDNA reverse transcription (Applied Biosystems) to produce cDNA. Briefly, the $10 \mu \mathrm{L}$ of treated RNA (2 mg) was 0.8 $\mu \mathrm{L} 25 \mathrm{x}$ dNTP $(100 \mathrm{mM})$ and $2 \mu \mathrm{L} 10 \mathrm{x}$ RT Random Primers-mixed before the $2 \mu \mathrm{L} 10 \times$ RT buffer, $4.2 \mu \mathrm{L} \mathrm{0.1 \%} \mathrm{DEPC} \mathrm{water,} \mathrm{and} 1 \mu \mathrm{L}$ MultiScribe $^{\mathrm{TM}}$ Reverse Transcriptase $(50 \mathrm{U} / \mu \mathrm{L})$ added. The tubecontained components were mixed gently and incubated for: 10 min at $25^{\circ} \mathrm{C} ; 120 \mathrm{~min}$ at $37^{\circ} \mathrm{C} ; 5 \mathrm{~min}$ at $85^{\circ} \mathrm{C}$.

\section{Real-Time Quantitative PCR}

For mRNA analyzing, Quantitative PCR (qPCR) was with the SYBR green (Applied Biosystems). All reactions were in triplicate. The Mean cycle threshold $\left(\mathrm{C}_{\mathrm{T}}\right)$ value of the EB viral mRNA, including BZLF1, BRLF1, EBNA1, EBNA2, and BNLF1 mRNA, was subtracted from $\beta$-actin $C_{T}$ values to obtain the normalized $C_{T}\left(\Delta C_{T}\right)$ value. $\Delta C_{T}$ : $\mathrm{C}_{\mathrm{T}}$ (BZLF1, BRLF1, EBNA1, EBNA2 or BNLF1)- $\mathrm{C}_{\mathrm{T}}$ ( $\beta$-actin). The $\Delta \mathrm{C}_{\mathrm{T}}$ value treated with F3a subtracted by untreated F3a to obtain the $\Delta \Delta \mathrm{C}_{\mathrm{T}}$ value. $\Delta \Delta \mathrm{C}_{\mathrm{T}}: \mathrm{C}_{\mathrm{T}}(\mathrm{F} 3 \mathrm{a})-\mathrm{C}_{\mathrm{T}}(0)$. Relative $\mathrm{EB}$ viral mRNA performance was calculated by $2^{-\Delta \Delta C T}$ method. The primers for mRNA analysis included: BRLF1 forward (5'-TCACTACACAAACAGACGCAGCCA-3') and reverse (5'-AATCTCCACACTCCCGGCTGTAA- $\left.3^{\prime}\right)$; BZLF1 forward (5'-AGAAGCACCTCAACCTGGAGACAA-3') and reverse (5'-CAGCGATTCTGGCTGTTGTGGTTT- $\left.3^{\prime}\right)$; BNLF1 forward (5'-ACACACTGCCCTGAGGATGG-3') and 
reverse

forward

(5'-ATACCTAAGACAAGTAAGCA-3');

reverse

(5'-GAGCGGGGAGATAATGTACA-3')

forward (5'-TAAAAGATGGCCGGACAAGG-3');

(5'-AGGGATGCCTGGACACAAGA-3')

reverse

(5'-TTGTGACAGAGGTGACAAAA- $3^{\prime}$ );

forward

(5'-CGTCTTCCCCTCCATCG-3') and

(5'-CTCGTTAATGTCACGCAC-3').

\section{Immunoblot Analysis}

Cell lysate was prepared to perform SDS-polyacrylamide gel electrophoresis and immunoblot analysis [24]. The protein expression was detected using anti-LMP1, anti-caspase, anti-

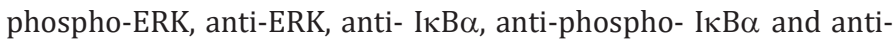
PARP antibodies, which were purchased from Thermo Scientific (CA, USA) and Cell signaling (Danvers, MA), respectively. The band intensities were scanning densitometry-quantitated.

\section{Raji Cell ROS Evaluating}

To determine the Raji cell ROS generation, the DCFH-DA was used when it penetrated the cell membranes and was intracellular esterase-hydrolyzed to form DCFH. Subsequently, the DCFH reacted with the intracellular ROS to produce highly fluorescent DCF. The 6 x $10^{5}$ Raji cells were DCFH-DA (50 $\left.\mu \mathrm{M}\right)$-pretreated for $30 \mathrm{~min}$ before the F3a went into the medium. After incubated at $37^{\circ} \mathrm{C}$ for $24 \mathrm{~h}$, the intracellular stress-produced ROS was detected by a Bio-Tek FLx800 microplate fluorescence reader (Winooski, VT, USA) with excitation and emission wavelengths of 485 and $528 \mathrm{~nm}$, respectively.

\section{Flow Cytometry-Analyed Apoptosis}

The flow cytometry was to quantitatively detect the apoptosis rate. Briefly, the Raji cells ( $\left.6 \times 10^{5} / \mathrm{mL}\right)$ were the $24 \mathrm{~h}$ F3a various concentration-treated, harvested and washed in ice-cold phosphate buffered saline, and resuspended in Annexin V-FITC and PI binding buffer for 15 min. They were the flow cytometry-analyzed; viable cells, with negative Annexin V-FITC and PI staining; apoptosis, with positive Annexin V-FITC and negative PI staining.

\section{Results}

The Effect of Ethyl Acetate Subfraction of Polygonum Cuspidatum Root Containing Emodin on Growing Raji Cells

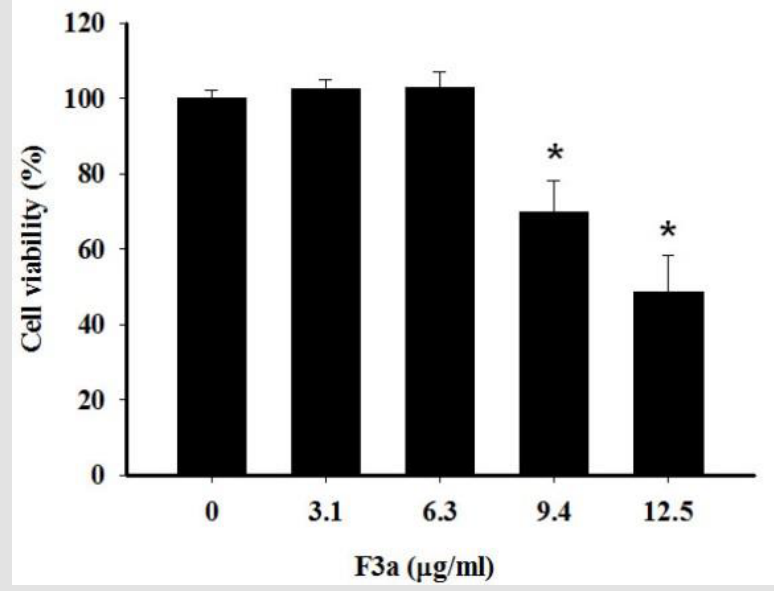

Figure 1: The $24 \mathrm{~h}$ F3a effect on the trypan blue dye exclusion assay-determined Raji relative cell $\left(6 \times 10^{5}\right.$ cells $/ \mathrm{mL}$ ) viability. The data were mean $\pm \mathrm{SD}$ in three independent experiments ( ${ }^{*} \mathrm{p}<0.05$ vs 0 : control).

For the ethyl acetate subfraction of Polygonum cuspidatum Root containing emodin (F3a) effect on growing Raji cells, the F3a went into Raji cells $\left(1 \times 10^{5} / \mathrm{mL}\right)$. After $24 \mathrm{~h}$ treatment, the cell viability was trypan blue-measured. The results showed that the decreased survival rate $(69.7 \pm 8.5 \%)$ after the $9.4 \mu \mathrm{g} / \mathrm{ml} \mathrm{F3a} \mathrm{treated} \mathrm{Raji} \mathrm{cells;}$ the increased concentration $(12.5 \mu \mathrm{g} / \mathrm{mL})$ for decreasing the cell viability $(48.8 \pm 9.6 \%)$. The regression equation analysis showed the F3a dose effect on the Raji cell survival rate. The F3a concentration $\left(\mathrm{CC}_{50}\right)$ which killed $50 \%$ of the cells was $12.08 \mu \mathrm{g} / \mathrm{mL}$ (Figure 1 ).

\section{Effect on EBV-Encoded LMP1}

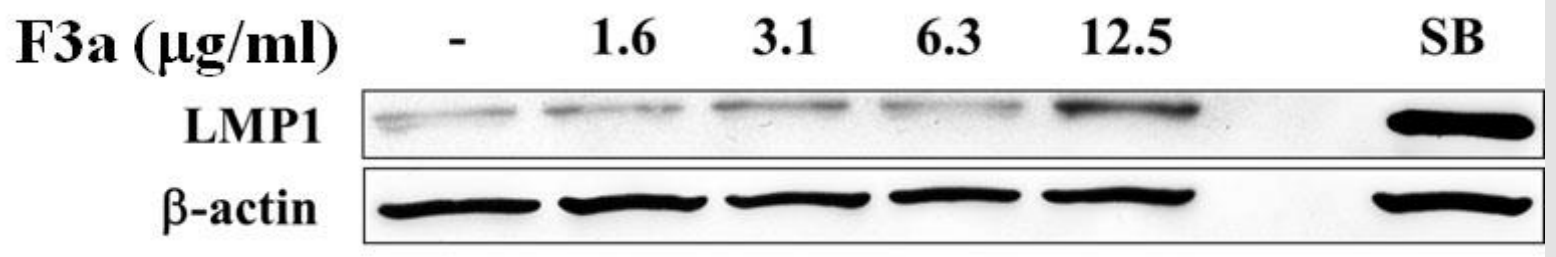

Figure 2: The EBV F3a-induced LMP1. The Raji cells $\left(6 \times 10^{5}\right.$ cells $\left./ \mathrm{mL}\right)$ were $24 \mathrm{~h} \mathrm{F3a}$ and SB-treated. The immunoblotting assay was using anti-LMP1 and $\beta$-actin monoclonal antibodies.

The EBV LMP1, an oncogene, will lead to cell proliferation, anti-apoptosis, immortalization, and eventually forming tumors, and making the tumor cells invade and metastasize, but the LMP1 overexpression or inhibition will make B cell apoptotic. Therefore, we further investigated the F3a effect on the Raji cell EBV-encoded
LMP1 protein. The Raji cells ( $6 \times 10^{5}$ cells $\left./ \mathrm{mL}\right)$ were treated with F3a (1.6-12.5 $\mathrm{mg} / \mathrm{mL}$ ) or EBV lytic inducer, SB (3 mM sodium butyrate) for $24 \mathrm{~h}$, and the LMP1 was immunoblotting analysisdetermined. The results showed the LMP1 protein-promoted cells with $12.5 \mu \mathrm{g} / \mathrm{mL}$ F3a or SB treatment (Figure 2). 


\section{Affected EBV Lytic and Latent Genes Expression}

To observe the F3a effect on Raji cell EBV genes, Raji cells were treated with different concentrations of F3a or EBV lytic inducer, SB for $24 \mathrm{~h}$. Total RNA was isolated from Raji cells and cDNA generated by reverse transcription. The mean cycle threshold $\left(\mathrm{C}_{\mathrm{T}}\right)$ values of EBV latent genes (EBNA1, EBNA2 and BNLF1), lytic genes (BZLF1 and BRLF1) and housekeeping gene ( $\beta$-actin) mRNA expression quantified by Real time PCR assay. Further, a normalized $\mathrm{C}_{\mathrm{T}}\left(\Delta \mathrm{C}_{\mathrm{T}}\right)$ value was by subtracting the $C_{T}$ value of $\beta$-actin from EBV latent/ lytic gene expression $\mathrm{C}_{\mathrm{T}}$ values. The relative gene expression by the $2^{-\triangle \triangle C T}$ method was analyzed. The results exhibited no F3a significant effects on BZLF1, EBNA1 and EBNA2 mRNA expression. The 12.5 $\mu \mathrm{g} / \mathrm{mL}$ F3a promoted the BRLF1 mRNA expression by fifteen fold; the $6.3-12.5 \mu \mathrm{g} / \mathrm{mL}$ F3a, the relative BNLF1 gene expression by six and five-fold, respectively; the SB, the BNLF1 expression by 23 -fold (Figure 3).
(A)

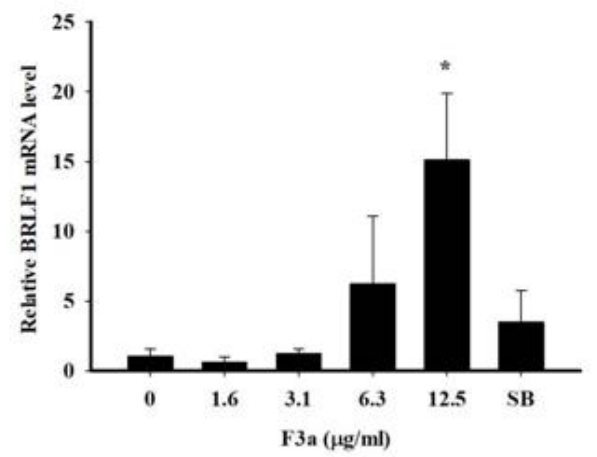

(B)

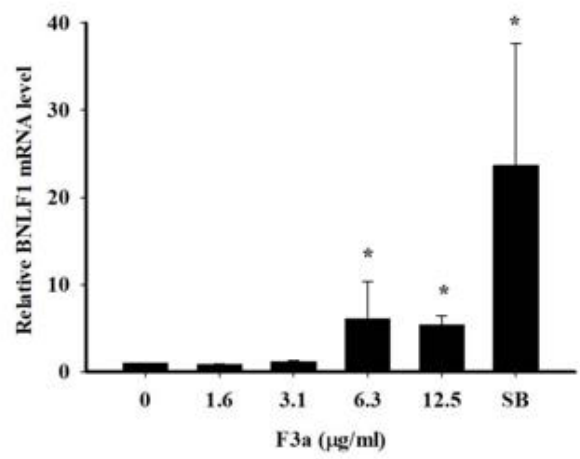

Figure 3: The F3a effect on EBV lytic and latent genes expression. The F3a (1.6-12.5 $\mu \mathrm{g} / \mathrm{mL})$ or SB (3 mM)-treated Raji cells (6 x $10^{5}$ cells $/ \mathrm{mL}$ ) were $24 \mathrm{~h}$. The real time PCR determined the normalized CT values. Relative mRNA level was determined by $2^{-\Delta \Lambda \mathrm{CT}}$ method. The data were mean $\pm \mathrm{SD}$ in the triplicate independent experiments $\left({ }^{*} \mathrm{p}<0.05 \mathrm{vs} 0\right.$ ).

\section{Induced Raji Cell ROS Production}

The F3a induced the Raji cell EBV encoded LMP1 expression. The previous literatures showed the EBV LMP1 and lytic cycle activation effect on the intracellular reactive ROS production. Therefore, the Raji cells were 24 h F3a-treated; DCFH (dichlorofluorescin)-DA was to determine whether F3a increased the Raji cell ROS production. Resultantly, with the $3.1 \mu \mathrm{g} / \mathrm{mL}$ and $6.3 \mu \mathrm{g} / \mathrm{mL}$ F3a-treated Raji cells, ROS compared with the cells untreated with F3a increased by 2.7 and 4 fold, respectively. The Raji cells exposed to higher concentration $(12.5 \mu \mathrm{g} / \mathrm{mL})$ increased at the ROS level and was 2.8 fold compared with the control group (Figure 4).

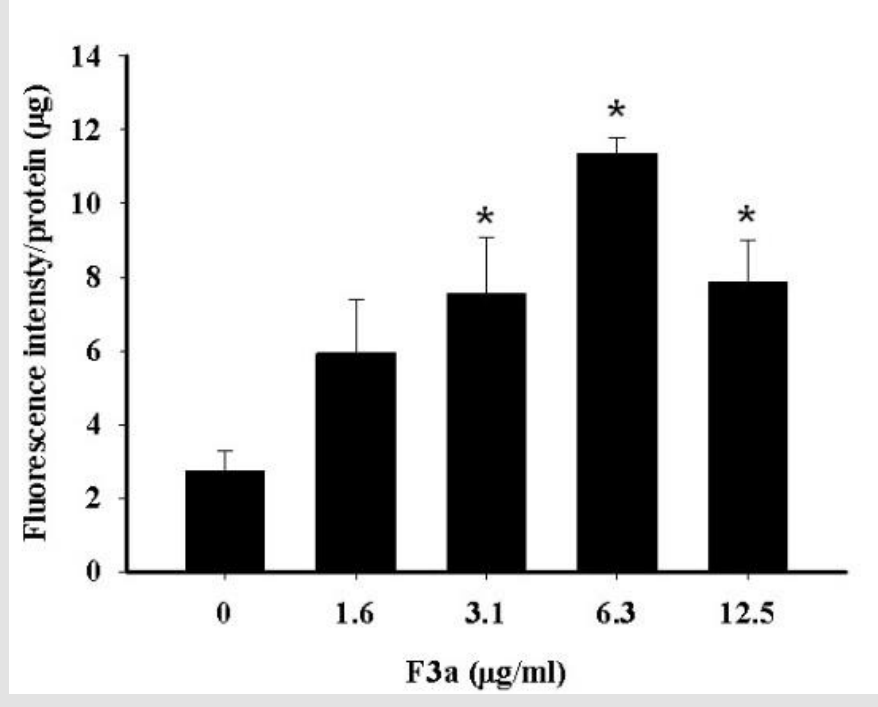

Figure 4: The F3a produced the Raji cell ROS. The cells were $24 \mathrm{~h}$ F3a-treated, and ROS production was DCFH-DA-measured $\left({ }^{*} \mathrm{p}<0.05\right.$ vs 0 : control). 


\section{Affected ERK and IкB $\alpha$ Phosphorylation}

The previous literatures indicated that EB-encoded LMP1 stimulated ERK phosphorylation and activated NF- $\kappa B$ entering to the nucleus, and thus the cells proliferate. The cytoplasmic NF$\kappa \mathrm{B}$-combined I $\mathrm{KB} \alpha$ inactivated the NF- $\kappa \mathrm{B}$ functions. The signalinduced I- $\kappa \mathrm{B} \alpha$ phosphorylated in the cytoplasm would promote the $\mathrm{I} \kappa \mathrm{B} \alpha$ degradation. As a result, the NF- $\kappa \mathrm{B}$ translocated to the nucleus allowed the NF- $\mathrm{KB}$ to transcriptionally activate several genes, including cell survival; proliferation; anti-apoptosis. Our result showed that F3a promoted the EB-encoded LMP1 expression. Further, the F3a effect on phosphorylated ERK/non-phosphorylated

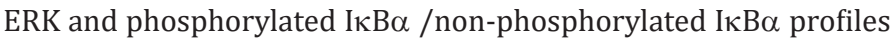
was investigated. The Raji cells were $24 \mathrm{~h}$ F3a or EBV lytic inducer, SB-treated. The phosphorylated ERK/non-phosphorylated ERK and phosphorylated I $\mathrm{I} B \alpha$ /non-phosphorylated I І $\kappa \mathrm{B} \alpha$ were immunoblotting-extracted and detected. Resultantly, the 6.3and $12.5 \mu \mathrm{g} / \mathrm{mL}$ F3a-treated phosphorylated ERK/non-phosphorylated ERK (Figure 5A) and phosphorylated IкB $\alpha$ / non-phosphorylated $\mathrm{I}-\kappa \mathrm{B} \alpha$ profiles (Figure $5 \mathrm{~B}$ ) significantly decreased in Raji cells. The phosphorylated ERK/non-phosphorylated ERK ratio decreased; phosphorylated I $\mathrm{B} \alpha$ /non-phosphorylated I $\mathrm{B} \alpha$ profiles increased in Raji cells with EBV lytic inducer, SB (Figures 5A \& 5B).

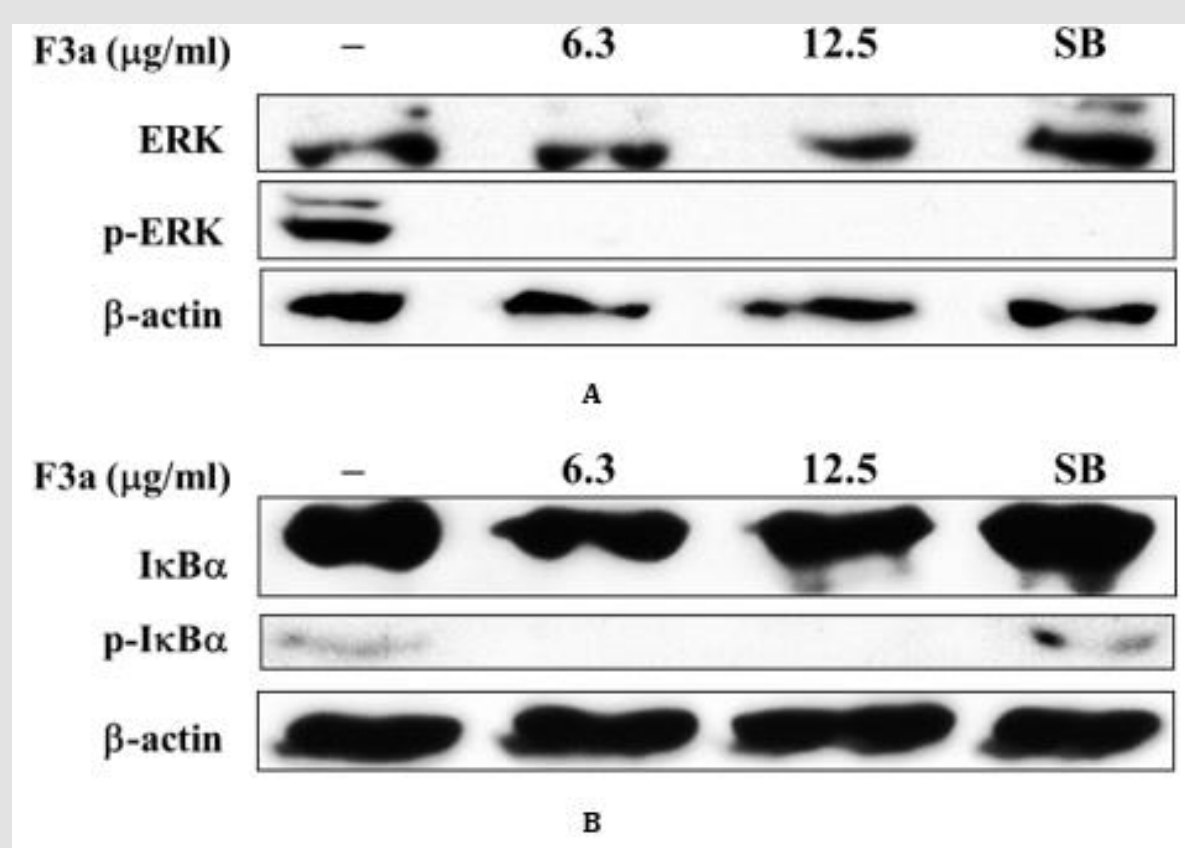

Figure 5: The $24 \mathrm{~h} \mathrm{F3a}(6.3-12.5 \mu \mathrm{g} / \mathrm{mL})$ or SB $(3 \mathrm{mM})$ effect on the Raji cell IKB $\alpha$ and ERK expression $\left(6 \times 10^{5}\right.$ cells $\left./ \mathrm{mL}\right)$.

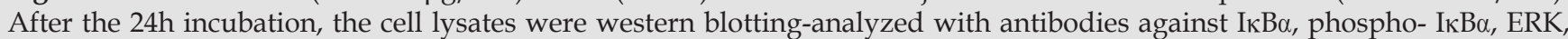

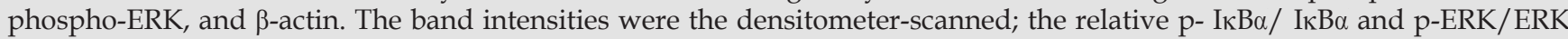
ratios, calculated.

\section{The Apoptosis-Related Protein Effect}

Our F3a induced the EBV LMP1 expression and inhibited the EBNA1 gene and ERK and $\mathrm{I} \kappa \mathrm{B} \alpha$ intracellular phosphorylation. In addition, the F3a promoted the Raji cell ROS performance. Therefore, whether the F3a induced cell death, caspase- 3 and PARP expression, apoptosis hallmark was further analyzed. The PARP and caspase-3 expression was immunoblotting-determined. Resultantly, the $12.5 \mu \mathrm{g} / \mathrm{mL}$ F3a significantly increased the cleaved caspase-3 and PARP expression (Figure 6).

\section{Induces Raji Cells Apoptosis}

The $24 \mathrm{~h}$ F3a effect on Raji cell apoptosis was investigated. Moreover, the Raji cells were stained with Annexin V and Propidium Iodide (PI), and flow cytometry-observed. Resultantly, the $6.3 \mu \mathrm{g} /$ $\mathrm{mL}$ F3a-treated early apoptotic cells increased from $7.18 \%$ to $17.74 \%$ (2.47 fold); the $12.5 \mu \mathrm{g} / \mathrm{mL}$ F3a-treated Raj cells, early apoptotic cells from $7.18 \%$ to $30.64 \%$ ( 4.27 fold): F3a-promoted Raji cell apoptosis (Figure 7). 


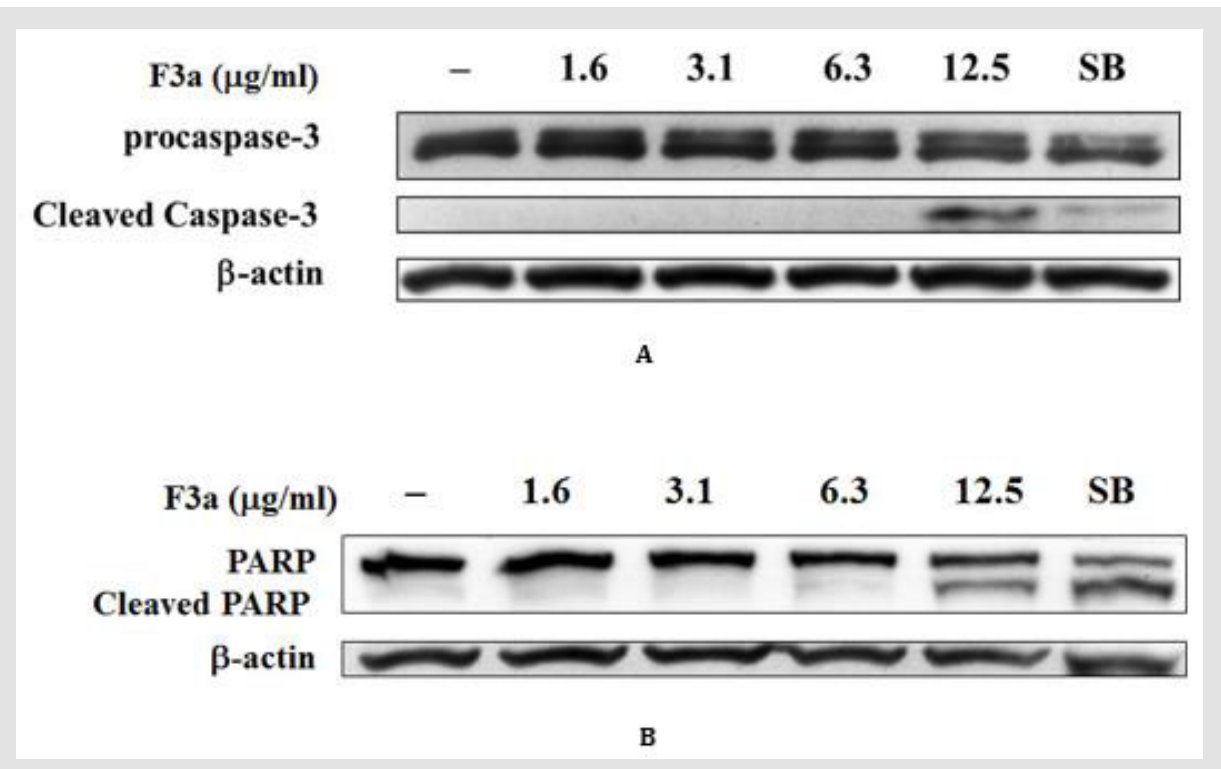

Figure 6: The F3a induced the caspase-3 and PARP cleavage in EBV-positive cells. The F3a (1.6-12.5 $\mu \mathrm{g} / \mathrm{mL})$ and SB-treated Raji cells were $24 \mathrm{~h}$. The immunoblotting assay was using the anti-caspase-3
a) Anti-PARP
b) $\beta$-actin monoclonal antibodies.

(A)

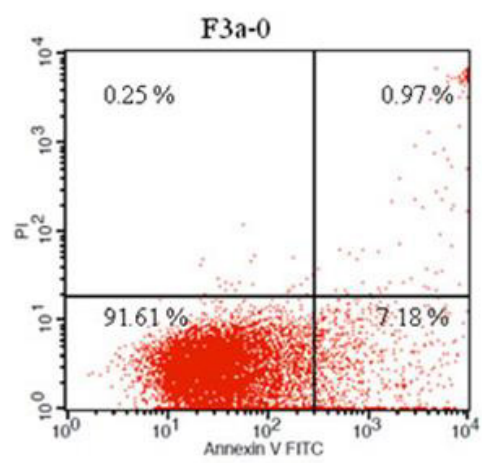

(B)

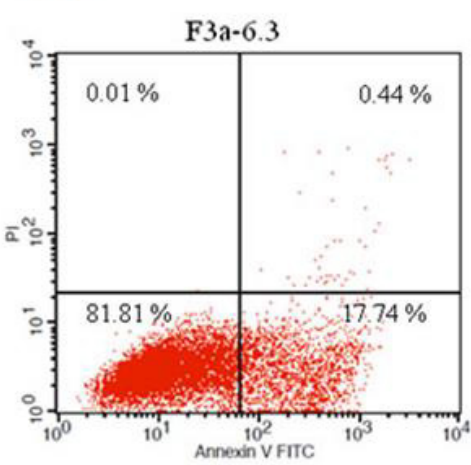

(C)

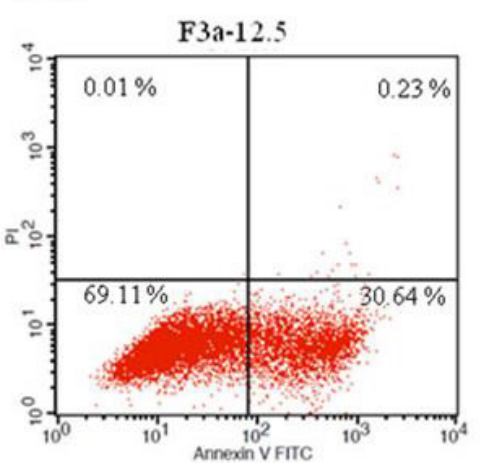

Figure 7: The Annexin-FITC/PI staining assay-determined F3a effect on Raji cell apoptosis. The Raji cells were $24 \mathrm{~h}$ F3a-treated and Annexin V-FITC and PI-stained. Note that most the intact cells were categorized into the double-negative group (lower left quadrant). The early apoptosis group was at a high percentage of Annexin V-positive and PI-negative staining (lower right quadrant); late apoptosis group, with a dead population categorized in the double-positive group (upper right quadrant).

\section{Discussion}

The previous literatures showed that LMP 1 directly activated the NF- $\mathrm{KB}$ by phosphorylating ERK and promoted the cell proliferation and immortality with the anti-apoptosis. The phosphorylated ERK also activated AP-1 or LMP to directly activate STAT3 and made tumor cells invade and metastasize [27]. However, many studies have shown cytotoxic LMP1: Hammerschmidt et al. found that cells-expressed LMP1 (a large amount) poisoned the cells [28]. Nitta et al. also stated that the LMP 1 poisoned cells and was related to inhibiting NF- $\kappa$ B activity and promoting apoptosis, which both were also in other cells, such as lymphoblasts, monocytes, and epithelial cells [29]. Brocqueville et al. found that LMP1 in MDCK renal epithelial cells increased with the apoptosis [30]. Therefore, our F3a affected the Raji cell NF- $\kappa$ B pathway by LMP1 (a large amount) because it reduced the cell $\mathrm{p}-\mathrm{I} \kappa \mathrm{B} / \mathrm{I} \kappa \mathrm{B}$ ratio and created the apoptosis with the nucleus without the intracellular NF- $\kappa$ B. Moreover, the ERK protein proliferated-cells were also observed. With the decreased p-ERK/ERK, the LMP1 could not phosphorylate ERK which decreased with the suppressed cell proliferation.

The $24 \mathrm{~h} \mathrm{F3a-treated} \mathrm{Raji} \mathrm{cells,} \mathrm{the} \mathrm{EBV} \mathrm{lysis} \mathrm{and} \mathrm{latency-related}$ genes were observed. The $12.5 \mu \mathrm{g} / \mathrm{mL}$ F3a promoted the BRLF1 mRNA by about 15 -fold. Chang et al. pointed that the Rta protein 
in the EBV lytic stage activated LMP1 [31], so it was speculated that the F3a likely promoted the Rta protein by increasing BRLF1 mRNA before increasing the BNLF1 mRNA and the LMP1. Cerimele et al. pointed LMP1, a ROS inducer in EBV latent type III [18]. Also in ours, the F3a-treated Raji cell ROS increased with increasing the F3a concentration. After $3.1 \mu \mathrm{g} / \mathrm{mL}$ and $6.3 \mu \mathrm{g} / \mathrm{mL}$ F3a-treated, the intracellular ROS increased by 2.7 and 4 times, respectively. Many studies have also pointed that the accumulated cellular ROS directly activated JNK and JNK/p38 MAPK signaling mechanism through FasL and induced apoptosis [32]. Therefore, the F3a promoted a large number of LMP1 and also greatly increased intracellular ROS, which triggered apoptosis.

\section{Conclusion}

The Polygonum cuspidatum ethyl acetate subfraction containing emodin increased the Raji cell BRLF1 and BNLF1 mRNA relative expression, the latency-related LMP1 proteins, and the ROS expression, and decreased the $\mathrm{p}-\mathrm{I} \kappa \mathrm{B} \alpha / \mathrm{I} \kappa \mathrm{B} \alpha$ and $\mathrm{p}$-ERK/ERK ratio. Resultantly, the cleaved caspase and PARP were produced, thereby inhibiting cell proliferation and causing apoptosis.

\section{Acknowledgment}

The Taiwan science and technology ministry, and Taiwan Liouying Chi Mei Medical Center- supported research grants, respectively, were: NSC100-2320-B-041-004-MY3 and MOST 1032320-B-041-002; CLFHR10332 and CLFHR10408.

\section{References}

1. Roizman B, Carmichael LE, Deinhardt F, De the G, Nahmias AJ, et al. (1981) Herpesviridae. Definition, provisional nomenclature, and taxonomy. The Herpesvirus Study Group, the International Committee on Taxonomy of Viruses. Intervirology 16(4): 201-217.

2. Niedobitek G, Hamilton Dutoit S, Herbst H, Finn T, Vetner M, et al. (1989) Identification of Epstein-Barr virus-infected cells in tonsils of acute infectious mononucleosis by in situ hybridization. Hum Pathol 20(8) 796-799.

3. Magrath I, Jain V, Bhatia K (1992) Epstein-Barr virus and Burkitt's lymphoma. Semin Cancer Biol 3(5): 285-295.

4. Jones JF, Shurin S, Abramowsky C, Tubbs RR, Sciotto CG, et al. (1988) T-cell lymphomas containing Epstein-Barr viral DNA in patients with chronic Epstein-Barr virus infections. N Engl J Med 318(12): 733-741.

5. Weiss LM, Movahed LA, Warnke RA, Sklar J (1989) Detection of EpsteinBarr viral genomes in Reed-Sternberg cells of Hodgkin's disease. N Engl J Med 320(8): 502-506.

6. Shibata D, Weiss LM (1992) Epstein-Barr virus-associated gastric adenocarcinoma. Am J Pathol 140(4): 769-774.

7. Zur Hausen H, Schulte Holthausen H, Klein G, Henle W, Henle G, et al. (1970) EBV DNA in biopsies of Burkitt tumours and anaplastic carcinomas of the nasopharynx. Nature 228 (5276): 1056-1058.

8. Lindahl T, Adams A, Bjursell G, Bornkamm GW, Kaschka Dierich C, et al. (1976) Covalently closed circular duplex DNA of Epstein-Barr virus in a human lymphoid cell line. J Mol Biol 102(3): 511-530.

9. Miller G (1990) The switch between latency and replication of EpsteinBarr virus. J Infect Dis 161(5):833-844.
10.Zur Hausen H, O Neill FJ, Freese UK, Hecker E (1978) Persisting oncogenic herpesvirus induced by the tumour promotor TPA. Nature 272(5651): 373-375

11. Luka J, Kallin B, Klein G (1979) Induction of the Epstein-Barr virus (EBV) cycle in latently infected cells by n-butyrate. Virology 94(1): 228-231.

12. Giot JF, Mikaelian I, Buisson M, Manet E, Joab I, et al. (1991) Transcriptional interference between the EBV transcription factors EB1 and R: both DNA-binding and activation domains of EB1 are required. Nucleic Acids Res 19(6): 1251-1258.

13. Fixman ED, Hayward GS, Hayward SD (1992) Trans-acting requirements for replication of Epstein-Barr virus ori-Lyt. J Virol 66(8): 5030-5039.

14. Vaysberg M, Hatton O, Lambert SL, Snow AL, Wong B, et al. (2008) Tumorderived variants of Epstein-Barr virus latent membrane protein 1 induce sustained Erk activation and c-Fos. J Biol Chem 283(52): 36573-36585.

15. Gahn TA, Sugden B (1995) An EBNA-1-dependent enhancer acts from a distance of 10 kilobase pairs to increase expression of the Epstein-Barr virus LMP gene. J Virol 69(4): 2633-2636.

16. Johannsen E, Koh E, Mosialos G, Tong X, Kieff E, et al. (1995) Epstein-Barr virus nuclear protein 2 transactivation of the latent membrane protein 1 promoter is mediated by J kappa and PU.1. J Virol 69(1): 253-262.

17. Chang Y, Lee HH, Chang SS, Hsu TY, Wang PW, et al. (2004) Induction of Epstein-Barr virus latent membrane protein 1 by a lytic transactivator Rta. J Virol 78(23): 13028-13036.

18. Cerimele F, Battle T, Lynch R, Frank DA, Murad E, et al. (2005) Reactive oxygen signaling and MAPK activation distinguish Epstein-Barr virus (EBV)-positive versus EBV-negative Burkitt's lymphoma. Proc Natl Acad Sci USA 102(1): 175-179.

19. Valko M, Leibfritz D, Moncol J, Cronin MT, Mazur M, et al. (2007) Free radicals and antioxidants in normal physiological functions and human disease. Int J Biochem Cell Biol 39(1): 44-84

20. Yi T, Zhang H, Cai Z (2007) Analysis of rhizoma polygoni cuspidati by HPLC and HPLC-ESI/MS. Phytochem Anal 18(5): 387-392.

21. Chu X, Sun A, Liu R (2005) Preparative isolation and purification of five compounds from the Chinese medicinal herb Polygonum cuspidatum Sieb. et Zucc by high-speed counter-current chromatography. J Chromatogr A 1097(1-2): 33-39.

22. Yiu CY, Chen SY, Chen YP, Lin TP (2013) Inhibition of the ethanolic extract from Polygonum cuspidatum root on the functions of Epstein-Barr virus latent membrane protein 1. J Food Drug Anal 21(1): 20-26.

23. Yiu CY, Chen SY, Huang CW, Yeh DB, Lin TP (2011) Inhibitory effects of Polygonum cuspidatum on the epstein-barr virus lytic cycle. J Food Drug Anal 19(2): 107-113.

24. Yiu CY, Chen SY, Yang TH, Chang CJ, Yeh DB, et al. (2014) Inhibition of Epstein-Barr virus lytic cycle by an ethyl acetate subfraction separated from Polygonum cuspidatum root and its major component, emodin. Molecules 19(1): 1258-1272.

25. Andrei G, Trompet E, Snoeck R (2019) Novel therapeutics for EpsteinBarr virus. Molecules 24(5): 997-1017.

26. Chang JS, Liu HW, Wang KC, Chen MC, Chiang LC, et al. (2005) Ethanol extract of Polygonum cuspidatum inhibits hepatitis B virus in a stable HBV-producing cell line. Antiviral Res 66(1):29-34.

27. Vaysberg M, Hatton O, Lambert SL, Snow AL, Wong B, et al. (2008) Tumorderived variants of Epstein-Barr virus latent membrane protein 1 induce sustained Erk activation and c-Fos. J Biol Chem 283(52): 36573-36585.

28. Hammerschmidt W, Sugden B, Baichwal VR (1989) The transforming domain alone of the latent membrane protein of Epstein-Barr virus is toxic to cells when expressed at high levels. J Virol 63(6): 2469-2475. 
29. Nitta T, Chiba A, Yamashita A, Rowe M, Israël A, et al. (2003) NF-кB is required for cell death induction by latent membrane protein 1 of Epstein-Barr virus. Cell Signal 15(4): 423-433.

30. Brocqueville G, Ndour PA, Ouk TS, Le Goff A, De Witte C, et al. (2013) LMP1-induced cell death may contribute to the emergency of its oncogenic property. PLoS One 8(4): e60743.

\section{ISSN: 2574-1241}

DOI: 10.26717/BJSTR.2021.35.005767

Tsuey-Pin Lin. Biomed J Sci \& Tech Res

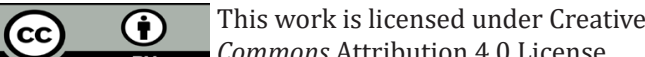

Submission Link: https://biomedres.us/submit-manuscript.php
31. Chang Y, Lee HH, Chang SS, Hsu TY, Wang PW (2004) Induction of Epstein-Barr virus latent membrane protein 1 by a lytic transactivator Rta. J Virol 78(23): 13028-13036.

32. Zhu X, Wang K, Zhang K, Zhu L, Zhou F, et al. (2014) Ziyuglycoside II induces cell cycle arrest and apoptosis through activation of ROS/JNK pathway in human breast cancer cells. Toxicol Lett 227(1): 65-73.

$\begin{array}{ll}\text { BIOMEDICAL } & \text { Assets of Publishing with us } \\ \text { RESEARCHES } & \text { - Global archiving of articles } \\ \text { - Immediate, unrestricted online access }\end{array}$

